\title{
Microfinance as Employment Generation Tool (Case Study of Pakistan 2001-02 to 2010-11)
}

\author{
Mohammad Salih Memon \\ Assistant Professor, Department of Business Administration Shah Abdul Latif University Khairpur \\ saleh.memona@salu.edu.pk \\ Mohammad Asif Channa, \\ Student of M. Phil, Department of Business Administration Shah Abdul Latif University Khairpur \\ asif.salu.dba@gmail.com \\ Izhar Ali Manganhar \\ Student of M. Phil, Department of Business Administration Shah Abdul Latif University Khairpur \\ Izhar.ali2010@yahoo.com
}

\begin{abstract}
The objective of this study is to know the contributions of Micro finance towards employment development through generating employment opportunities to the alit class of urban and rural community. For this purpose quantitative research techniques were used to collect the data. The data was collected through secondary sources from economic survey from 2011-12 and labor force survey 2010-2011 and from annual plans of Pakistan from 2001-02 to 2012-13. Mainly 8 to 10 micro finance banks and micro finance institutes and some NGOs are taken into study.

The results express the positive contributions of micro finance to the employment that leads to poverty reduction and improved living standard. In contrast micro finance through supporting the employment generates sustainable solutions of other economic problems like poverty, good education, better health etc.
\end{abstract}

Keywords: Microfinance; Employment; Poverty; Pakistan.

\section{Council for Innovative Research}

Peer Review Research Publishing System

Journal: INTERNATION JOURNAL OF COMPUTERS AND TECHNOLOGY

Vol. 13, No. 5

editorijctonline@gmail.com

www.cirworld.org/journals 


\section{INTRODUCTION}

Microfinance provides financial support to the less privileged sections of the society to enable them to make their livelihood. The assistance is in terms of moderate amounts essential for starting economic activity for substance.

Although microfinance programs began in Pakistan in the 2000s, there has been slow growth due to inadequate legal, regulatory, social measures. Microfinance considered as core technique helps the country for economic growth and in reducing poverty by creating employment opportunities especially "Self-Employment".

As (Wagner, 2002) said that Microfinance has been prove to be most important and vital source for poverty reduction that leads to employment generation opportunities. Employment is fundamental source of solving various basic problems of any economy. Employment is the action of giving work to someone or an individual who survive in smooth manner by meeting his/her basic needs from different sources independently.

The informal business sector, especially micro enterprise provides a path for employment opportunities so in this regard there is a need of developing microenterprise. So main objective of Micro finance is developing the small and medium enterprises as the small firms and sole trader can survive. Financial sector is significant for creation and preservation of jobs in developing countries. Pakistan is also one of that developing countries striving for reducing poverty by developing the micro enterprises on the basis of Micro financing. Microfinance as an input provided to people who lacks in equity for exploring their skills, knowledge, experiences for generating money and Self Employment for themselves and also to become source of income for others by generating employee opportunities. (Mawa, 2008). Microfinance enables people "To sustain present, and to secure the future." through Self-Employment. As we know that Pakistan $9^{\text {th }}$ largest labor force in the world, the total labor force in country was 57.24 million; out of this 3.40 million people are unemployed. (Labor Force Survey 2010-11). Further Labor Force Survey 2011-12 has not been published.

As we know that strong work force plays an important role in economic growth through competitiveness. In this regard micro finance institutions are established to provide loans to unemployed people to set up their own business as they can survive own selves rather depending on others. Micro finance generates employee opportunities for social well-being in two ways.

1. Directly: By expanding network of Micro finance institutions throughout the country. Commonly a micro Finance Institute consists of 10 to 15 banking staff and 3 to 6 non-banking staff. Means a Micro Finance Institute generates employment opportunities not only for 20 people but become the strong supporting hand for 20 families.

2. Indirectly: The main motive of any MFI working in any area of the world is to strengthen the microenterprises, and to promote the "Self-Employment" in the shape of short-term debt to low income level people as they can enhance their business.

Micro Finance is just like a seed to grow a plant of employment that fruits in the shape of growth, sustainability, improved living standard.

Micro Finance acts as a soap that kills the germs of poverty and unemployment for developing healthy society (Seibel, (2003).)

\section{LITERATURE REVIEW}

The major purpose of this research paper is to know the impacts of microfinance on employment as a supportive attribute used to fight against unemployment problems faced by Pakistani people. No doubt in Pakistan Micro Finance Institutes are working mainly for promoting "Self-Employment Development" by generating various kinds of opportunities.

Micro Finance is like major financial resource derived from external environment for fulfilling the capital requirements especially for micro enterprise development. The major sources of Micro financing may be MFIs, MF Banks (currently 8 Micro Finance Banks are working In Pakistan), and NGOs (Khalily, 2004).

Before this various studies are conducted on Micro Finance and its impacts on various economic problems like poverty, unemployment, economical and social growth. Mainly Micro Finance helps in poverty alleviation. Recently Micro Finance for strengthening the micro enterprises and employment provides various financial services other than the micro credit such as savings, money transfers and insurance as well, as a result that the microfinance is not only responsible to promote the current employment status of the poor people but also striving to secure the future of the poor people.

Micro finance is a program/ strategy offered to improve the living standards of poorest people of developing countries by tightening their business, self employment skills and efficiencies (Ghalib, 2004).

Micro Finance has been also attributing for reducing the gender inequality among the less educated poor people, especially for those individuals who are not giving the basic rights and importance to the women.

In recent years, microfinance has become successful strategy to overcome poverty leads to employment development (Morduch,1999).

Micro Finance is striving not only to generate employment opportunities for men but also trying at major level to promote the women employment because women possess rational decision making ability as compare to men, women generally take decisions that will be more beneficial for their families. As a result, Pakistani women will contribute financial decisions that will improve nutrition, health and literacy within their families; whereas men may misuse that financial resources for their own desires may be harmful for family future (Mayoux, (2001a). 
Micro Finance can be considered as a ring of chain that links the employment with the economic growth so for building that chain microfinance has targeted the poverty and unemployment as a big enemy or germ. Micro Finance has also promoted the "Self Employment Concept" especially in rural regions of the country in agricultural sector development (Liu, 2008).

For the developing countries majority of people who are aware slightly about the role of micro finance think that micro finance is only solution for solving economic problems but the reality is that the in Pakistan Micro Finance Institutes become failure to achieve their desired objective as profitability and social development. On the other hand microfinance has been proved as essential tool for generating employment opportunities for lower income people who have not suitable access over the public sector and private sector empowerment but one of the major negative perspectives of micro fiancé institutes that they are charging high interest rates on the small loans provided. As a result the mostly entrepreneurs for covering that cost of capital and for generating high turnovers they do their jobs themselves rather than hiring other employees. By studying various literatures it can be concluded as that the micro finance currently considered as the leading tool for poverty reduction, generating more and advanced employment opportunities for those who lacks in capital, and support them to grow as by meeting the needs of current inflation era. Micro Finance enables poor people to survive with the better nutrition, health and education through "Self-Employment Development." The major motive of my this research to know the impacts of microfinance not only on employment but also on the other related economic variables such as poverty, unemployment, economic growth and micro finance has achieved success in development of poor people at micro level by developing their living standards, their children's education etc.

\section{METHODOLOGY}

This study is conducted to know the role of micro finance as employment generation tool for poor people living in rural and urban areas of Pakistan. This research is totally based on secondary data which is taken from economic survey $2011-12$ and labor force survey 2010-2011 and from annual plans of Pakistan from 2001-02 to 2012-13 and from some other sources. Annually Loan Disbursement Amounts in Rs. Million of 8 to 10 micro Finance banks, Institutes are taken into consideration, and their contributions towards GDP and Employment is measured.

Later on the gathered data was put into and screened through Statistical Package for Social Sciences (SPSS).

\section{TECHNIQUE USED}

The regression technique is used for processing the data in SPSS 16 and for collecting the results. There are two variables are used Micro Finance Loan Disbursement is independent variable and Employed Labor Force is dependent variable.

\section{REULTS}

$M F=\alpha+E M P \beta+\mu$

Co-efficient of determination R-Square states that Model is fit and Micro Finance Loan Disbursement is rightly predicting the Dependent variable employed Labor Force which is a good sign. Furthermore it is positively and strongly associated with Employed Labor Force. Details of Results are shown in Table.

\begin{tabular}{|l|c|c|c|c|}
\hline Model & R & R-Square & $\begin{array}{c}\text { Adjusted R } \\
\text { Square }\end{array}$ & $\begin{array}{c}\text { Std. Error of the } \\
\text { Estimate }\end{array}$ \\
\hline 1 & .830 & .689 & .644 & 3.45858 \\
\hline
\end{tabular}

. Predictors: (Constant), MF Loan Disbursement

Coefficients

\begin{tabular}{|c|c|c|c|c|c|}
\hline \multirow{2}{*}{ Model } & \multicolumn{2}{|c|}{$\begin{array}{c}\text { Un-standardized } \\
\text { coefficient }\end{array}$} & $\begin{array}{c}\text { Standardized } \\
\text { coefficients }\end{array}$ & & Sig. \\
\cline { 2 - 5 } & B & Std. Error & Beta & T & .000 \\
\hline MF Loan Disbursement & .000 & .000 & .830 & 3.937 & .006 \\
& & & & & \\
\hline
\end{tabular}

Dependent variables: Employed labor force 


\section{CONCLUSIONS}

This study concludes that the Micro Finance contributes to the employment development in urban and rural areas of Pakistan. Micro Finance has supported the low level class of society to stand on their own feet rather than depending on others or government. In this regard Government has also to take steps to strengthen the micro fiancé sector as it can become stronger factor of employment generation tool. If government becomes failure to provide employment opportunities to majority general public then the micro finance can become right hand for solving the unemployment problems and also can control the poverty level in upcoming years. This research also concludes that the other than the loan facilities now a day's micro finance institutes are trying to provide additional services to their customers like savings, insurance at micro level.

Furthermore it is stated that effective utilization of Micro Finance loan disbursement amount enables the individual to live as "An Employer not An Employee".

\section{BIBLIOGRAPHY}

1. Ghalib, A. (2004). Systemic Knowledge Management: Developing a Model for managing Organisational Assets for Strategic and Sustainable Competitive Advantage,. Journal of Knowledge Management Practice 5.

2. Khalily. (2004). Qualitative Approach to Impact Analysis of Microfinance. Journal Of International Development, 331 353.

3. Mawa, B. (2008). Impact of Micro-finance Towards Achieving Poverty Alleviation. Pakistan Journal of Social Sciences, 5 (9) , 876-882.

4. Mayoux, L. (2001a). Impact Assessment of Micro Finance: Towards a Sustainable Learning Process. Paper Produced from the DFID. Enterprise Development Impact Assessment Information Service (EDIAIS) website: www.enterpriseimpact@org.uk

5. Seibel, H. (2003).). History Matters in Microfinance. . International journal of Microfinance and Business Development, , $10-12$.

6. Wagner, R. F. (2002). Analysis of the Effects of Microfinance on Poverty Reduction. Jonathan Morduch and Barbara Haley. .

7. Morduch, J. (Decmber 1999). The Microfinance Promise. Journal of Economic Literature , 1569-1614.

8. Liu, M. (2008). "Financial Structure, Development of Small and Medium Enterprises, and Income Distribution in the People s Republic of China". " Asian Development Review.

9. Gilal R.G, J. M. (2011). "Microfinance Industry In Pakistan- Challenges and Opportunities". Interdisciplinary Journal Of Contemporary Research In Business, Vol. 3, no. 1.

10. Annual Plan 2008-2009 Poverty Reduction and Human Development . www.finance.gov.pk: Finance Division Governemnt Of Pakistan.

11. Pakistan Microfinance Network (2013). Microwatch - An Annual Assessment of Microfinance Industry in Pakistan. Islamabad, Pakistan Microfinance Network.

12. Economic Survey| (2012-2013). Ministry of Finance Government Of Pakistan, www.finance.gov.pk.

\section{Author's Biography}

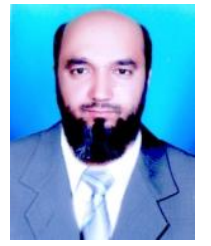

"Completed my MBA from Shah Abdul Latif University Khairpur, Sindh Pakistan in Finance and appointed as lecturer there in september 2004 and completed my M. Phil in Finance from IQRA University Karachi in 2010 and promoted as Assistant Professor, now recently submitted my Ph.D thesis for foreign evaluation from Shah Abdul Latif University Khairpur in Public finance under the supervision of Dr. Syed Munir Ahmed Shah". 